\title{
Targeted killing of colorectal cancer cell lines by a humanised IgGI monoclonal antibody that binds to membrane-bound carcinoembryonic antigen
}

\author{
PJ Conaghan ${ }^{1,2,3}$, SQ Ashraf ${ }^{1,2,3}$, MG Tytherleigh ${ }^{1,2}$, JL Wilding', E Tchilian', D Bicknell', N JMcC Mortensen ${ }^{2}$ \\ and WF Bodmer*,I
}

'Cancer Research UK, Cancer \& Immunogenetics Laboratory, Weatherall Institute of Molecular Medicine, Headington, Oxford, UK; ${ }^{2}$ Department of Colorectal Surgery, John Radcliffe Hospital, Headington, Oxford, UK

\begin{abstract}
The distribution of carcinoembryonic antigen (CEA) in colorectal cancer (CRC) differs from that in normal colorectal tissue, being found on all borders of the cell membrane and hence enabling access to intravenous antibody, making CEA a good target for antibody-based therapy. The distinctive anti-CEA antibody, PRIA3, binds only membrane-bound CEA. Humanised PRIA3 (hPRIA3) was assessed both in vitro cytotoxicity and binding assays with colorectal cancer cell lines expressing varying levels of CEA. Human peripheral blood mononuclear cells (PBMCs) and purified natural killer (NK) cells were used as effectors. The in vitro assays demonstrated hPRIA3 CEA-specific binding and antibody-dependent and CEA-specific killing of human colorectal cancer cell lines by human PBMCs. The effect increased with increasing concentration of antibody and surface CEA, and was lost by using the parent murine IgGI PRIA3. Killing was also blocked by antibody to the Fc- $\gamma$ IIIA receptor. Purified human NK cells were effective at much lower effector:target ratios than unfractionated PBMCs, indicating that NK cells were the main mediators of hPRIA3-based CEAspecific killing. The results support the development of hPRIA3 for therapy of colorectal cancer.
\end{abstract}

British Journal of Cancer (2008) 98, I217-1225. doi:I0.1038/sj.bjc.6604289 www.bjcancer.com

Published online 18 March 2008

(c) 2008 Cancer Research UK

Keywords: PRIA3; CEA; ADCC; colorectal cancer

There has been a recent resurgence of interest in the use of monoclonal antibodies for the treatment of cancer, mostly in the setting of metastatic disease, and already a number of antibodies have been licensed for use (for review see Reichert and ValgeArcher, 2007). Antibody therapy directed at cell surface components, in particular cell membrane receptors, has the potential to exploit the specificity and sensitivity of the immune system's ability to recognise cell membrane receptors, and so to achieve selective therapeutic effects without the toxicity of standard chemotherapy. As a result antibody therapy has become a useful adjunct to the treatment of cancer. This comes despite poor initial results with murine antibodies (Clynes, 2006). The development of chimeric and humanised antibodies has led to the development of a second generation of antibodies that hardly, if at all, stimulate the development of human anti-mouse antibodies, and which are potent activators of the immune system (Carter, 2006). Currently, about 19 antibodies are licensed for clinical use, 11 of which are for the treatment of cancer (Reichert and Valge-Archer, 2007). There are, it is estimated, at least a further 150 antibodies in

\footnotetext{
* Correspondence: Professor WF Bodmer;

E-mail: walter.bodmer@hertford.ox.ac.uk

${ }^{3}$ These authors contributed equally to this work.

Revised 21 January 2008; accepted 31 January 2008; published online 18

March 2008
}

development. Antibody use has had a major impact on the treatment of haematological malignancies with excellent response rates seen using rituximab (anti-CD20) in follicular and B cell nonHodgkin's Lymphoma (Olszewski and Grossbard, 2004). Their impact in solid tumours has, however, been less dramatic. A major reason for this must be the limited penetration of antibodies, being large glycoproteins, into the tumour. Three antibodies have been licensed by the US FDA for use in advanced colorectal cancer. These include antibodies against EGFR (cetuximab) and VEGF (bevacizumab). A problem with the former is the presence of EGFR on cells of a variety of normal tissues leading to a degree of nonspecificity with respect to cancer. The EGFR antibody also appears to be effective in only a proportion of cancer patients. It is therefore important to look for other potential antigens to use as targets to broaden the number of patients for which antibodybased immunotherapy may be effective.

Carcinoembryonic antigen (CEA or CEACAM5) was first recognised as a potential human tumour-specific antigen in the 1960s (Gold and Freedman, 1965; Berinstein, 2002). CEA has characteristics that make it a useful target for antibody therapy in colorectal cancer (CRC). It is overexpressed in the vast majority of CRCs (Chan and Stanners, 2007). More importantly, however it is always aberrantly expressed in CRC. While the CEA expressed on normal colonic epithelium is inaccessible to IgG antibody, being found only on the luminal surface of the cell, this expression pattern changes in the neoplastic cell so that CEA is additionally 
expressed on the basal and lateral membranes (Hammarstrom, 1999) making it accessible to blood-borne antibody. Although a member of the Ig superfamily, CEA is linked to the cell membrane by a glycophosphatidylinositol (GPI) anchor (Thompson et al, 1991) and thus has no direct intracellular signaling motif. The functional significance, if any, of its overexpression in colorectal cancer remains unclear. The biggest disadvantage of CEA as a target is that it is readily cleaved from the cell surface and so shed into the blood stream from tumours, either directly or via the lymphatics, which is why the level of serum CEA has been used in the clinic as a marker for screening and recurrence, especially of colorectal cancer (Chau et al, 2004). Serum CEA binds to most of the currently used anti-CEA antibodies hindering them from reaching their target and so largely mitigating against any potential clinical effect. This is, however, not the case for the murine antibody, mPR1A3 developed in the ICRF laboratories in London by Richman and Bodmer (1987).

PR1A3 was shown to target the B3 domain and GPI anchor of the CEA molecule by Durbin et al, 1994 (see Figure 1), and was subsequently humanised by Stewart et al, 1999. Murine PR1A3 has been shown to react poorly with soluble CEA, which lacks the GPI anchor, and has been used in immunoscintigraphy for the detection of colorectal tumours with a high degree of specificity (Granowska et al, 1989). In contrast to EGFR and VEGF, there are so far no unconjugated, or 'naked' antibodies to CEA being used for the treatment of colorectal cancer. The anti-CEA antibodies that are currently used in pilot trials, are administered as radioconjugates (Wong et al, 2004; Liersch et al, 2007).

Strong evidence for the suggestion that the antitumour effects of antibodies are mediated mainly by ADCC (antibody-dependent cellular cytotoxicity) comes from mouse knockout studies which showed that antibody antitumour effects were largely absent in mice lacking the appropriate Fc receptor (Clynes et al, 1998). In humans, natural killer (NK) cells that express the CD16 Fc $\gamma$ receptor are thought to be the main cell type that could mediate ADCC of tumours (Arnould et al, 2006). Several criteria, therefore, need to be fulfilled before an antibody can be considered for therapy (Reichert and Valge-Archer, 2007). Humanised antibodies are more potent activators of the human immune system than their murine equivalents. Internalisation of

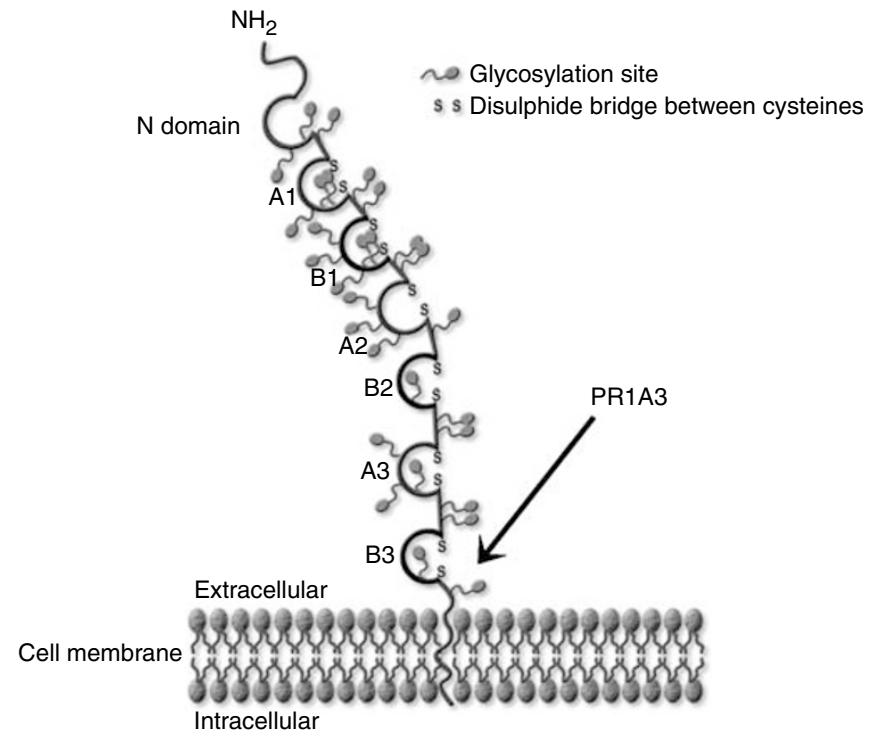

Figure I Schematic diagram showing the binding site of PRIA3 on CEA. The antibody binds at a site involving parts of the GPI anchor and the B3 domain of CEA. Access to the epitope appears to be blocked when CEA is released from the cell. antibody-antigen complexes, leading to a loss of antibody complexes available for binding to Fc receptor-bearing cells, will diminish the effectiveness of antibody-based killing.

This study has three aims. First to analyse the ability of humanised hPR1A3 to react with a panel of colorectal cancer cell lines expressing high and low levels of CEA. Second to explore the use of hPR1A3 in an in vitro cytotoxicity model and to compare human PBMC with partially purified NK cells as effectors for ADCC. The third aim was to investigate whether soluble CEA inhibited the ADCC activity of hPR1A3 in vitro.

\section{MATERIALS AND METHODS}

\section{Cell lines}

The gastric carcinoma cell line MKN45 (Motoyama et al, 1979) was obtained from Cell Services LIF, Cancer Research UK. All other cell lines were colorectal cell lines:

HCT-116 (Brattain et al, 1981) and SKCO-1 (Fogh, 1975) were originally obtained from ATCC; GP5d (Solic et al, 1995) and HT55(Watkins and Sanger, 1977) were obtained from ECACC; LS174T (Tom et al, 1976) was obtained from BH Tom, NW University Med Centre, Chicago, Ill, USA, PC/JW (Paraskeva et al, 1984) was obtained from C. Paraskeva, Directors Lab, CRUK, London and C70 (Browning et al, 1993) was established in the Cancer and Immunogenetics Laboratory.

All cell lines were maintained in culture in Dulbecco's modified Eagle's (E4) medium with $1 \%$ L-glutamine, $10 \%$ fetal calf serum (FCS) and $1 \%$ penicillin/streptomycin. They were incubated at $37^{\circ} \mathrm{C}$ in a humidified $10 \% \mathrm{CO}_{2}$ environment. For the chromiumrelease and EuTDA assays the cells were suspended in 2\% RPMI1640 medium with $1 \%$ glutamine and $10 \%$ FCS.

\section{Peripheral blood mononuclear cells}

Peripheral blood mononuclear cells (PBMCs) were isolated either from fresh whole blood from healthy laboratory volunteers, having taken informed consent, or from leucodepletion filters obtained from single donors following blood donation (Courtesy of Cristina Navarrete, Colindale National Blood Service, London, UK). White cells were eluted from the filter using $5 \mathrm{~mm}$ ethylenediaminetetraacetic acid. Fresh whole blood was mixed with an equal volume of an RPMI-1640/citrate solution ( $40 \mathrm{ml} \mathrm{3.3 \%}$ sodium citrate, $2 \mathrm{ml} 5 \mathrm{~mm}$ 2-mercaptoethanol, $200 \mathrm{ml} \mathrm{RPMI}-1640$ + hepes) as an anticoagulant.

Both sources of PBMC were then processed in an identical fashion. Following Ficoll/hypaque density centrifugation, the PBMC layer was withdrawn from the interface and washed once with RPMI-1640 to remove excess Ficoll, spinning at $800 \mathrm{~g}$ (Boyum, 1968) and then a second time, spinning at $200 \mathrm{~g}$ for $10 \mathrm{~min}$ to remove platelets. The resulting PBMCs were resuspended in RPMI$1640 / 10 \% \mathrm{FCS} / 1 \%$ glutamine (complete RPMI-1640), kept at room temperature and used within $12 \mathrm{~h}$ of preparation.

\section{Antibodies}

PR1A3 The original is a murine IgG1 $\kappa$ monoclonal antibody to CEA (Richman and Bodmer, 1987) that was later humanised (Stewart et al, 1999). Both murine (mPR1A3) and humanised (hPR1A3) antibodies were obtained from the Biotherapeutics Development Unit, Clare Hall, Cancer Research UK, London, UK.

Anti-CD16 Two different clones of this antibody were used: MEM154 (Biovendor Laboratory Medicine Inc.) and 3G8 (BD Biosciences, Pharmingen, USA). Both are murine monoclonal IgG1 $\kappa$ antibodies against the human Fc $\gamma$ IIIA receptor (CD16A; FCGR3A). $\mathrm{F}(\mathrm{ab})_{2}$ derived from the $3 \mathrm{G} 8$ clone was obtained from Ancell Corp, Bayport, MN, USA. 
Anti-prostate specific membrane antigen Murine monoclonal antibody 107-1A4 to PSMA was kindly provided by Robert Vessella (Univ Washington, USA).

Polyclonal rabbit anti-mouse antibody This was obtained from DAKO A/S, Denmark, and was diluted to $1: 100$ in RPMI-1640/1\% FCS.

Anti- $\beta$-galactosidase antibody clone 4C7 (Durbin and Bodmer, 1987), was obtained from the Monoclonal Antibody Service, Clare Hall, Cancer Research UK, London, UK, and used at a final concentration of $0.4 \mu \mathrm{g} \mathrm{ml}^{-1}$ in RPMI-1640/1\% FCS.

AUA-1 This was obtained from the Monoclonal Antibody Service, Clare Hall, Cancer Research UK, London, UK (Epenetos et al, 1982). It has been shown to be an anti-EpCam antibody (Spurr et al, 1986).

FITC-conjugated murine anti-human IgG and FITC-conjugated rabbit anti-mouse IgG These were obtained from Sigma-Aldrich, Poole, UK.

CD3-FITC, CD16-PE, CD56-APC, IgG1-FITC (isotype control), IgG1$P E$ (isotype control) and IgG1-APC (isotype control) These were obtained from BD Biosciences Pharmingen, Oxford, UK.

\section{Chromium-release cytotoxicity assay}

Peripheral blood mononuclear cells were prepared as above and suspended at a concentration of $1 \times 10^{7} \mathrm{ml}^{-1}$ in RPMI-1640 supplemented with $10 \%$ FCS and $1 \%$ glutamine (complete medium). $2 \times 10^{6}$ target cells were centrifuged at $400 \mathrm{~g}$ for $5 \mathrm{~min}$, decanted and labelled by resuspending the pellet in $0.1 \mathrm{ml}$ of 7.4MBq of $\mathrm{Na}_{2}^{51} \mathrm{CrO}_{4}$. This cell suspension was incubated at $37^{\circ} \mathrm{C}$ for 60-100 min depending on the optimal labelling time for the particular cell line. Optimal labelling time had previously been determined by choosing the labelling time with the highest maximal lysis:background radioactivity ratio. The cells were then washed twice with RPMI-1640 and suspended in complete RPMI1640 at a concentration of $1 \times 10^{5}$ cells per ml. Target cells $(100 \mu \mathrm{l}$ $\left.\left(1 \times 10^{4}\right)\right)$ and PBMCs $\left(100 \mu \mathrm{l}\left(1 \times 10^{6}\right)\right)$ were added to microcentrifuge tubes to give an effector: target ratio of $100: 1$. Various antibody concentrations $(20 \mu \mathrm{l})$ were then added to the relevant tubes. Triton $(120 \mu \mathrm{l}$ of $5 \%)$ was added to $100 \mu \mathrm{l}$ of target cells to obtain maximum release values. All tubes were made up to the same volume using complete RPMI-1640. The tubes were spun at $200 \mathrm{~g}$ for $2 \mathrm{~min}$ and the pellet of combined target and effector cells was incubated at $37^{\circ} \mathrm{C}$ for $4 \mathrm{~h}$ in the presence of antibody. The tubes were then spun at $200 \mathrm{~g}$ for $5 \mathrm{~min}$ and $35 \mu \mathrm{l}$ of the supernatant added to $100 \mathrm{ul}$ Optiphase Supermix (Perkin Elmer, Boston, MA, USA) in a 96 -well plate. The ${ }^{51} \mathrm{Cr}$ concentration in each well was then determined using a Microbeta plate reader.

\section{Fluorescence-based EuTDA cytotoxicity assay}

Five microlitres of BATDA (Blomberg et al, 1996) (Perkin Elmer, Boston, MA, USA) were added to $2 \times 10^{6}$ target cells suspended in complete RPMI-1640 and incubated for $10-25 \mathrm{~min}$ at $37^{\circ} \mathrm{C}$ depending on the optimal labeling time for the particular cell line, determined as described for the ${ }^{51} \mathrm{Cr}$-release assays. The relative concentrations of target cells and antibody in the microcentrifuge tubes were similar to those used for the ${ }^{51} \mathrm{Cr}$ release assay. However, varying effector:target cell ratios were used for the fluorescence-based assay. After spinning at $200 \mathrm{~g}$ for $2 \mathrm{~min}$ the tubes were incubated at $37^{\circ} \mathrm{C}$ for $2 \mathrm{~h}$ and then spun again at $200 \mathrm{~g}$ for $5 \mathrm{~min}$. A total of $20 \mu \mathrm{l}$ of the resulting supernatant was added to $200 \mu \mathrm{l}$ of Europium in black 96-well plates and the resulting fluorescence was then read in a time-resolved fluorometer using an excitation wavelength of $340 \mathrm{~nm}$ and an emission wavelength of $615 \mathrm{~nm}$.

\section{CEA ELISA assay}

CEA levels were determined using a $\beta$-galactosidase/anti$\beta$-galactosidase ELISA (Durbin and Bodmer, 1987). Cells were plated onto a poly-L-lysine coated 96-well Nunc-Immuno PolySorp plate at a concentration of $2.5 \times 10^{4}$ cells per well. Murine PR1A3 was used as the CEA-detecting antibody with rabbit anti-mouse antiserum as the secondary antibody. The GAG complex of $\beta$-galactosidase with anti- $\beta$-galactosidase antibody was made by dissolving $\beta$-galactosidase (E.coli $\beta$-galactosidase lyophilised powder; Sigma-Aldrich, Poole, Dorset, UK) at a concentration of $500 \mathrm{U} \mathrm{ml}^{-1}$ in $100 \mathrm{mM}$ TRIS/ $100 \mathrm{mM} \mathrm{MgCl}_{2} / 100 \mathrm{mM}$ 2-mercaptoethanol with $300 \mu \mathrm{g} \mathrm{ml}^{-1}$ of $4 \mathrm{C} 7$ and incubating this complex at $4{ }^{\circ} \mathrm{C}$ overnight. The complex so formed was then added at a dilution of $1: 750$ in RPMI-1640/1\% FCS. The GAG complex binds to free antigen-binding sites on the rabbit anti-mouse IgG antibody, which is already bound to the PR1A3 attached to the CEA on the cells. The substrate 4-methylumbelliferyl-B-D-galactoside (Sigma-Aldrich, Poole, Dorset, UK) was first prepared at a concentration of approximately $0.3 \mathrm{mg} \mathrm{ml}^{-1}$ in a buffer of $1 \mathrm{~mm}$ $\mathrm{MgCl}_{2} / 100 \mathrm{~mm}$ 2-mercaptoethanol . After stirring for $30 \mathrm{~min}$, the solution was filtered to remove excess substrate. This substrate solution was added to each well to start the reaction. After incubation for $40 \mathrm{~min}$ in the dark at room temperature, fluorescence was measured using an excitation wavelength of $365 \mathrm{~nm}$ and an emission wavelength of $445 \mathrm{~nm}$.

\section{Flow cytometric analysis of CEA internalisation}

The concentration of cells to be analysed was adjusted to $1 \times 10^{6} \mathrm{ml}^{-1}$ and the cells washed once with phosphate-buffered saline (PBSA) containing 2\% FCS and then centrifuged at $400 \mathrm{~g}$ for five minutes. The resulting pellet was resuspended in cold PBSA containing $2 \%$ FCS and incubated on ice with either $100 \mu \mathrm{l}$ of hPR1A3 at $20 \mu \mathrm{g} \mathrm{ml}^{-1}, 100 \mu \mathrm{l}$ of AUA- 1 at $15 \mu \mathrm{g} \mathrm{ml}^{-1}$ or a medium control for $30 \mathrm{~min}$. The cells were next washed again, with PBSA containing $2 \%$ FCS and incubated in a water bath at $37^{\circ} \mathrm{C}$ for $0,1,2$ or $3 \mathrm{~h}$. The cells were then incubated with a 1:50 dilution of FITCconjugated anti-human-IgG for hPR1A3 and a $1: 100$ dilution of FITC-conjugated anti-murine IgG for AUA-1 on ice in the dark for 30 min before being washed again and resuspended in PBSA containing $2 \%$ FCS. The cells were then passed through a fluorescence-activated cell sorting (FACS) Calibur flow cytometer and the results analysed using CellQuest software.

\section{NK cell enrichment}

Fresh PBMC or eluted PBMC from leucodepletion filters were enriched for NK cells using a Human NK Cell isolation kit (Miltenyi Biotec) following the manufacturer's instructions. This involved adding the NK cell Biotin-Antibody cocktail $(10 \mu \mathrm{l}$ per $10^{7}$ cells) which contained antibodies against T cells, B cells, stem cells, dendritic cells, monocytes, granulocytes and erythroid cells. Following incubation for $10 \mathrm{~min}$ at $4^{\circ} \mathrm{C}$, the NK Cell magnetic Microbead Cocktail was added. This was left for $15 \mathrm{~min}$ at $4^{\circ} \mathrm{C}$ and the cells then washed with MACS buffer (PBSA/0.5\% FCS/2 mM EDTA) and centrifuged. The cell pellet was resupended in $0.5 \mathrm{mls}$ MACS buffer and then passed through an LS magnetic column to remove cells that bound the antibodies in the cocktail. The cells that passed through were then collected and suspended in RPMI-1640 with and without IL-2 (Peprotech) at $10 \mathrm{ng} \mathrm{m}^{-1}$ and incubated overnight at $37^{\circ} \mathrm{C}$. Aliquots pre and post sorting were taken for FACS analysis with the antibodies CD3, CD56 and CD16 and the appropriate isotype controls. Thus, $1 \times 10^{6}$ cells were suspended in $2 \mathrm{ml}$ of FACS buffer (PBSA/1\%FCS/ $1 \%$ sodium azide) 
and centrifuged. The supernatant was removed and the cells resuspended in the residual buffer. The antibodies were then added and left for $20 \mathrm{~min}$ at $4{ }^{\circ} \mathrm{C}$ before washing and then fixing with $300 \mu \mathrm{l}$ of $2 \%$ paraformaldehyde. The fixed cells were analysed on a FACS Calibur flow cytometer. Gating of the lymphocyte population in the forward versus side scatter plot revealed a purity of at least $85 \%$ with respect to CD16 and CD56 binding. The resulting NK cells were used in cytotoxicity assays with hPR1A3 against SKCO-1, which is known to express CEA.

\section{Effect of soluble CEA on PR1A3-induced ADCC}

Purified CEA, obtained from human liver colorectal metastasis, was purchased from Chemicon and diluted in RPMI-1640 for use in ADCC assays with NK cells (CD3-/CD56 + /CD16+) that were isolated from PBMC from a healthy volunteer. CEA was added to achieve final concentrations of 2 and $10 \mu \mathrm{g} \mathrm{ml}^{-1}$. This concentration far exceeds any concentration that would be found in the serum of a colorectal cancer patient. A level above $5 \mathrm{ng} \mathrm{ml}^{-1}$ is generally accepted as being raised. Patients with CEA levels above $15 \mathrm{ng} \mathrm{ml}^{-1}$ have been found to have a worse prognosis (Wiratkapun et al, 2001). The cytotoxicity assay was then carried out as described above.

FACS analysis for competitive inhibition of hPR1A3 binding in the presence of soluble CEA

Soluble CEA at a final concentration of $10 \mu \mathrm{g} \mathrm{ml}^{-1}$ was added to hPR1A3 (final concentration $20 \mu \mathrm{g} \mathrm{ml}^{-1}$ ). The mixture was incubated in a $1.7 \mathrm{ml}$ eppendorf microtube for $45 \mathrm{~min}$ at room temperature. Humanised PR1A3 alone, at a concentration of $20 \mu \mathrm{g} \mathrm{ml}^{-1}$, and medium alone were similarly incubated in a microtube. Cells to be assayed with these various mixtures were adjusted to a concentration of $1 \times 10^{6} \mathrm{ml}^{-1}$ in RPMI- 1640 complete medium and washed with FACS buffer (PBSA/1\%FCS/1\% sodium azide). The resulting pellet was resuspended in $10 \mu \mathrm{l}$ FACS buffer and then incubated on ice with $100 \mu \mathrm{l} 20 \mu \mathrm{g} \mathrm{ml}^{-1} \mathrm{mPR} 1 \mathrm{~A} 3$, hPR1A3/CEA (as prepared above) or medium control for $30 \mathrm{~min}$. The cells were then washed twice with FACS buffer and incubated on ice in the dark for $30 \mathrm{~min}$ with a 1:50 dilution of FITCconjugated anti-human-IgG (for hPR1A3). The resulting labelled cells were washed again with $2 \mathrm{ml}$ of FACS buffer and centrifuged at $400 \mathrm{~g}$. The supernatant was removed completely and the cells resuspended in $300 \mu \mathrm{l}$ of $2 \%$ paraformadehyde in PBSA. The labelled cells were analysed using a FACS Calibur flow cytometer as described before.

\section{Data analysis}

Percentage lysis of the cell lines in the cytotoxicity assays was calculated as (experimental release-background release)/(maximum release-background release) $\times 100$. Percentage specific lysis was calculated as (experimental release-antibody independent release) $/$ (maximum release-antibody independent release) $\times 100$. The s.e.m. of multiple experiments was calculated using Graphpad Prism software, San Diego, CA, USA. Standard normal distribution tests were used to assess the significance of the differences found.

\section{RESULTS}

\section{hPR1A3 binds to membrane-bound CEA and the} antibody-antigen complex is not internalised after $3 \mathrm{~h}$

Humanised PR1A3 showed specific binding to MKN45, a high CEA-expressor. After three hours incubation of MKN45 at $37^{\circ} \mathrm{C}$ with hPR1A3, no change was observed in the amount of antibody detected on the cell surface (Figure 2A). This is in contrast to the results obtained in similar experiments using the anti-EpCAM monoclonal antibody, AUA-1 (Figure 2B). In that case there is already a significant reduction in the cell surface expression of EpCAM after incubation for $1 \mathrm{~h}$ at $37^{\circ} \mathrm{C}$ indicating a fairly rapid internalisation of the surface EpCAM/anti-EpCAM complex. These data show that the CEA/anti-CEA(PR1A3) complex is not significantly internalised even after $3 \mathrm{~h}$ of incubation at $37^{\circ} \mathrm{C}$ (Figure 2).

\section{hPR1A3 causes dose-dependent lysis of the high CEA-expressing cell line, MKN45}

MKN45 was used as a high CEA expressing cell line in cellular cytotoxicity assays with ${ }^{51} \mathrm{Cr}$ using different antibody concentrations. In the absence of antibody, PBMCs effected a low but significant level of spontaneous killing. The level of killing increased with increasing concentrations of antibody, as would be expected for ADCC (Figure 3).

\section{Colorectal cancer cell lines express varying levels of CEA}

The level of CEA expression on a subset of cell lines was assessed using an ELISA assay with mPR1A3, and is given in Table 1 as mean arbitrary fluorescence units ( \pm s.d.).

These data correlate well with those obtained from FACS analysis, RT-PCR and micro-array expression data (see Supplementary Figure 1).
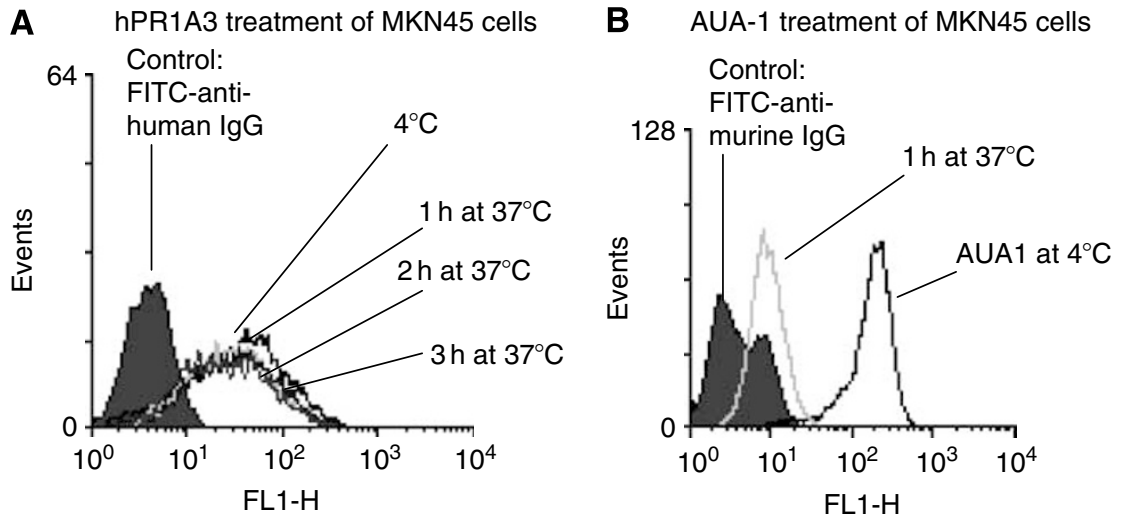

Figure 2 Time-course FACS analysis of hPRIA3 binding to CEA-expressing MKN45 cells. The cell line was labeled with primary antibody (PRIA3 or $A \cup A-I$ ) at $4^{\circ} \mathrm{C}$ and then incubated for varying times at $37^{\circ} \mathrm{C}$ before addition of secondary antibody (FITC-conjugated anti-human IgG or anti-mouse IgG respectively). (A) Analysis over time suggests that the CEA-PRIA3 complex is not internalised within $3 \mathrm{~h}$ of binding to CEA. (B) Binding of the monoclonal antibody AUA-I to EpCAM on the surface of MKN45 cells leads to internalisation within one hour. 


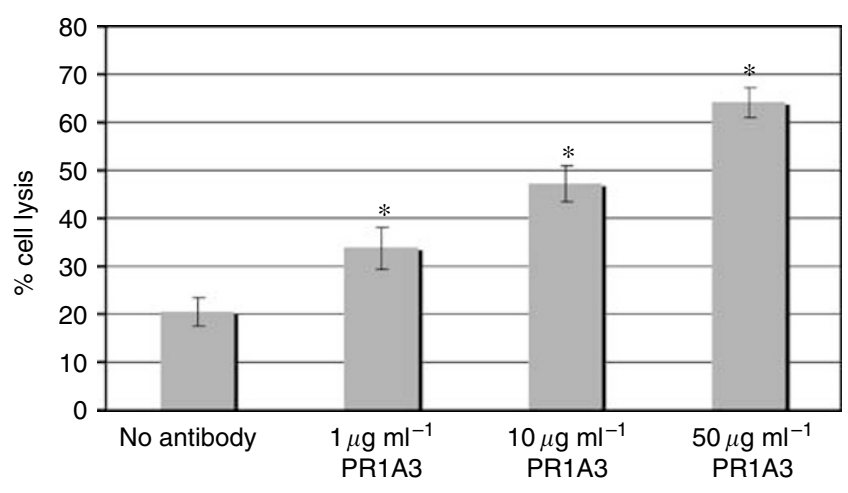

[hPR1A3]

Figure 3 Humanised PRIA3-induced ADCC-mediated lysis is dependent on the concentration of antibody. $\mathrm{Cr}$-release ADCC assays were done using MKN45 as CEA-expressing target cells and human PBMC as effectors at a ratio of $100:$ I effectors to targets. Columns represent mean $\%$ lysis without antibody and with varying concentrations of hPRIA3. These data shown are from the analysis of 14 separate experiments using MKN45 as the target cell and with triplicate wells for each condition in each experiment. Error bars indicate standard error of the mean (s.e.m.). * Indicates that significance of values is $P<0.05$ compared with samples given no antibody.

Table I CEA expression determined by GAG-ELISA and given as mean arbitrary fluorescence units \pm s.d.

\begin{tabular}{lc}
\hline Cell line & CEA expression (mean \pm s.d.) \\
\hline SKCO-I & $26804( \pm 1322)$ \\
PC-JW & $20160( \pm 2124)$ \\
LSI74T & $19833( \pm 2618)$ \\
MKN45 & $19741( \pm 1769)$ \\
HT55 & $11954( \pm 1667)$ \\
HT29 & $4688( \pm 1185)$ \\
HCT- 116 & $1995( \pm 1035)$ \\
\hline
\end{tabular}

\section{The level of hPR1A3-mediated ADCC depends on the level of CEA expression}

HCT-116 was identified by FACS, ELISA and RT-PCR assays to have no or at most a very low level of CEA expression. The killing of the high expressing cell line MKN45 was therefore compared with that of HCT-116 by hPR1A3 in the presence of human PBMC using a EuTDA assay. While MKN45 was killed as expected, there was no increase in lysis of HCT-116 above spontaneous killing even with the highest concentration of antibody (Figure 4A). The variation in hPR1A3-based ADCC lysis between cell lines expressing different levels of CEA was assessed using PBMC and a EuTDA assay. The results shown in Figure 4B indicate a good correlation between CEA levels and the degree of hPR1A3mediated killing (Figure 4).

\section{hPR1A3-mediated ADCC-based killings depends on the Fc portion of the antibody}

Since the murine IgG1 isoform does not associate strongly with the human Fc $\gamma$ IIIA receptor (Lubeck et al, 1985), mPR1A3 was compared with hPR1A3 in killing assays on MKN45. The results (Figure 5) show that murine PR1A3 did not kill above background, in contrast to hPR1A3. This adds to the support for the specificity of hPR1A3-based killing and suggests its dependence on appropriate interaction with an $\mathrm{Fc} \gamma$ receptor (Figure 5).

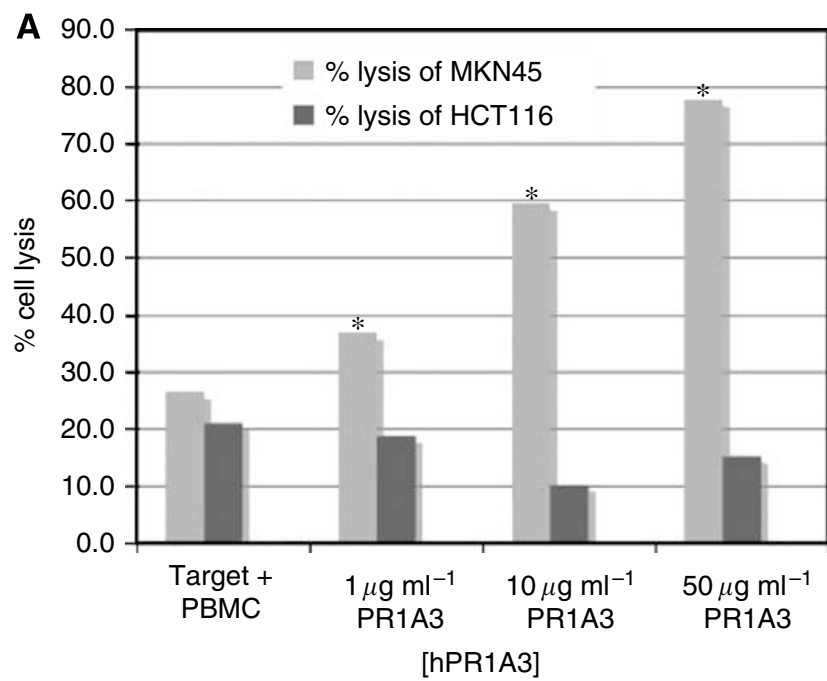

ADCC in cell lines using hPR1A3

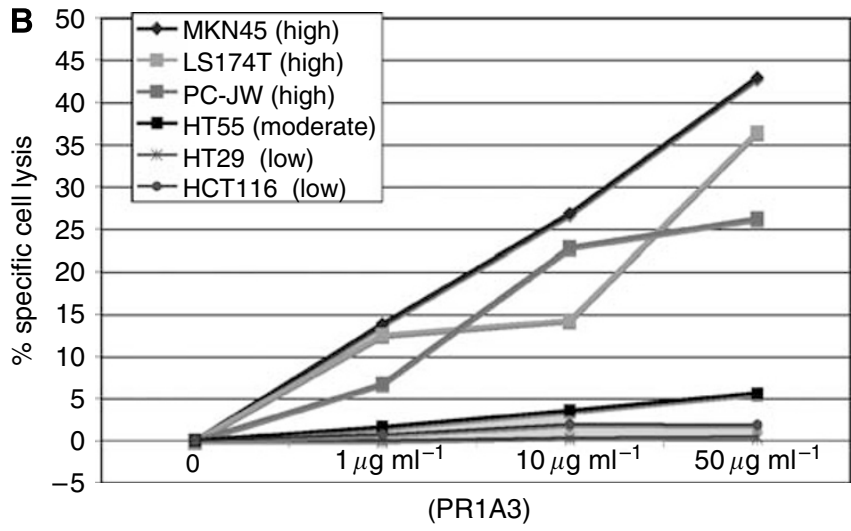

Figure 4 hPRIA3-mediated ADCC lysis of colorectal cancer cell lines depends on their level of CEA expression. (A) Effect of increasing concentrations of hPRIA3 on lysis of CEA-positive (MKN45) and -negative (HCT-I |6) cell lines. Fluorescence-based ADCC assays were done using human PBMCs as effector cells in a ratio of 100: I with target cells. Columns represent \% lysis in the presence of both target and effector cells with no, or with increasing concentrations of hPRIA3. $* P<0.05$ comparing the cell lysis between MKN45 and HCTI I6. (B) Comparison of hPRIA3mediated ADCC based lysis in cell lines with different levels of CEA expression (shown in parentheses) based on results in Table I. The EuTDA-based ADCC assay was done using human PBMCs as effector cells at ratios of 100:I with the various target cell lines. Nonspecific spontaneous killing levels have been subtracted to reflect antibody-specific lysis only.

hPR1A3-dependent and spontaneous killing are both inhibited by an anti-CD16 antibody, but only antibodydependent killing is inhibited by an $\mathrm{F}\left(\mathrm{ab}^{\prime}\right)_{2}$ of anti-CD16

Since the NK effector cells in PBMC, which are presumed to mediate the majority of antibody-dependent killing, do so via the CD16 (Fc $\gamma$ IIIA) receptor (Titus et al, 1987; Lanier et al, 1988; Moretta et al, 1989), the blocking effects on hPR1A3 killing of MKN45 by anti-CD 16 and a $\mathrm{F}(\mathrm{ab})_{2}$ of the same antibody were investigated (Figure 6).

The results of blocking experiments with two different concentrations of the reagents are shown in Figure 6 . These data show that anti CD16 completely blocked both spontaneous and hPR1A3-induced killing. To ensure that this was a direct effect of blocking the CD16 antibody receptor and not simply a consequence of adding a second antibody which might compete for 


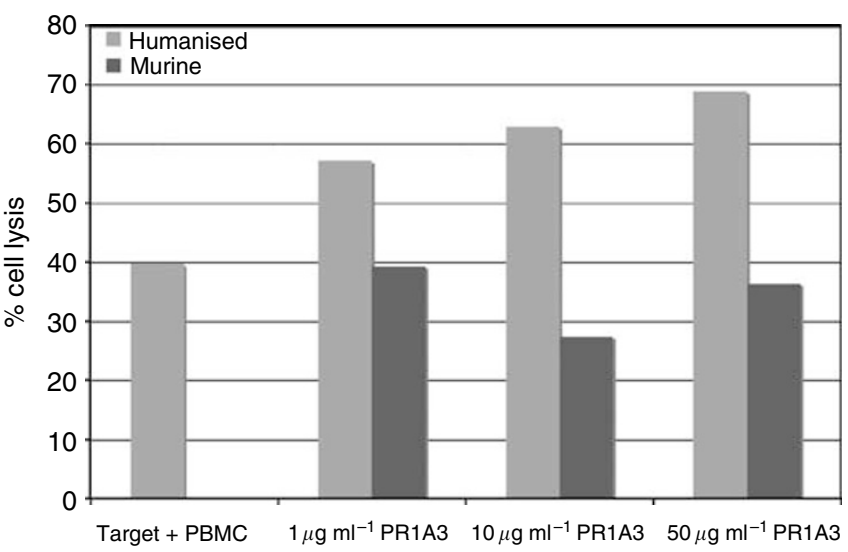

[PR1A3]

Figure 5 Comparison of humanised $|g G|$ and murine $|g G|$ isotypes of PRIA3 in fluorescence-based ADCC assays using human PBMCs as effectors and the MKN45 cell line. Effector:target ratios of I00: I were used in all assays. Columns represent mean \% lysis from triplicate wells containing both target and effector cells with no, or with increasing concentrations of hPRIA3.

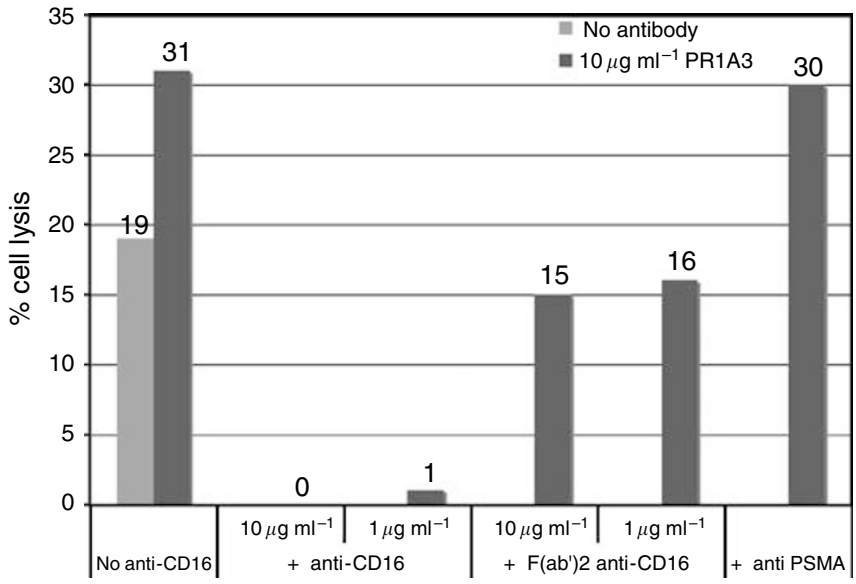

Figure 6 Effect of whole or $F\left(a b^{\prime}\right)_{2}$ anti-CD 16 on hPRIA3-mediated lysis. Fluorescence-based ADCC assays were done using human PBMCs as effector cells in a ratio of 100: I with MKN45 target cells. Columns represent mean \% lysis from triplicate wells containing both target and effector cells $\pm 10 \mu \mathrm{g} \mathrm{ml}^{-1} \mathrm{hPRIA} 3 \pm$ second antibody as indicated. The anti-CD 16 constructs and anti-PSMA control were added at the same time as the effector cells without prior incubation.

Fc-receptor sites, we added a non-specific antibody against prostate membrane-specific antigen instead of anti-CD16 and this did not block hPR1A3-mediated killing of MKN45.

In marked contrast to the blocking effects of whole CD16 antibody, the $\mathrm{F}(\mathrm{ab})_{2}$ of the anti-CD16, which lacks the Fc-portion of the antibody required for binding to the CD16 receptor on effector cells, abolished only antibody-dependent killing but did not affect the spontaneous lysis.

Purified NK cells are able to elicit ADCC with hPR1A3 at much lower effector:target ratios than are unfractionated PBMC

To establish that the major killing effect seen with hPR1A3 was actually due to NK cells as conventionally defined, purified NK cells were used in assays of hPR1A3 killing of the high CEA expressing colorectal cell line, SKCO-1. NK cells were enriched
A Presorting
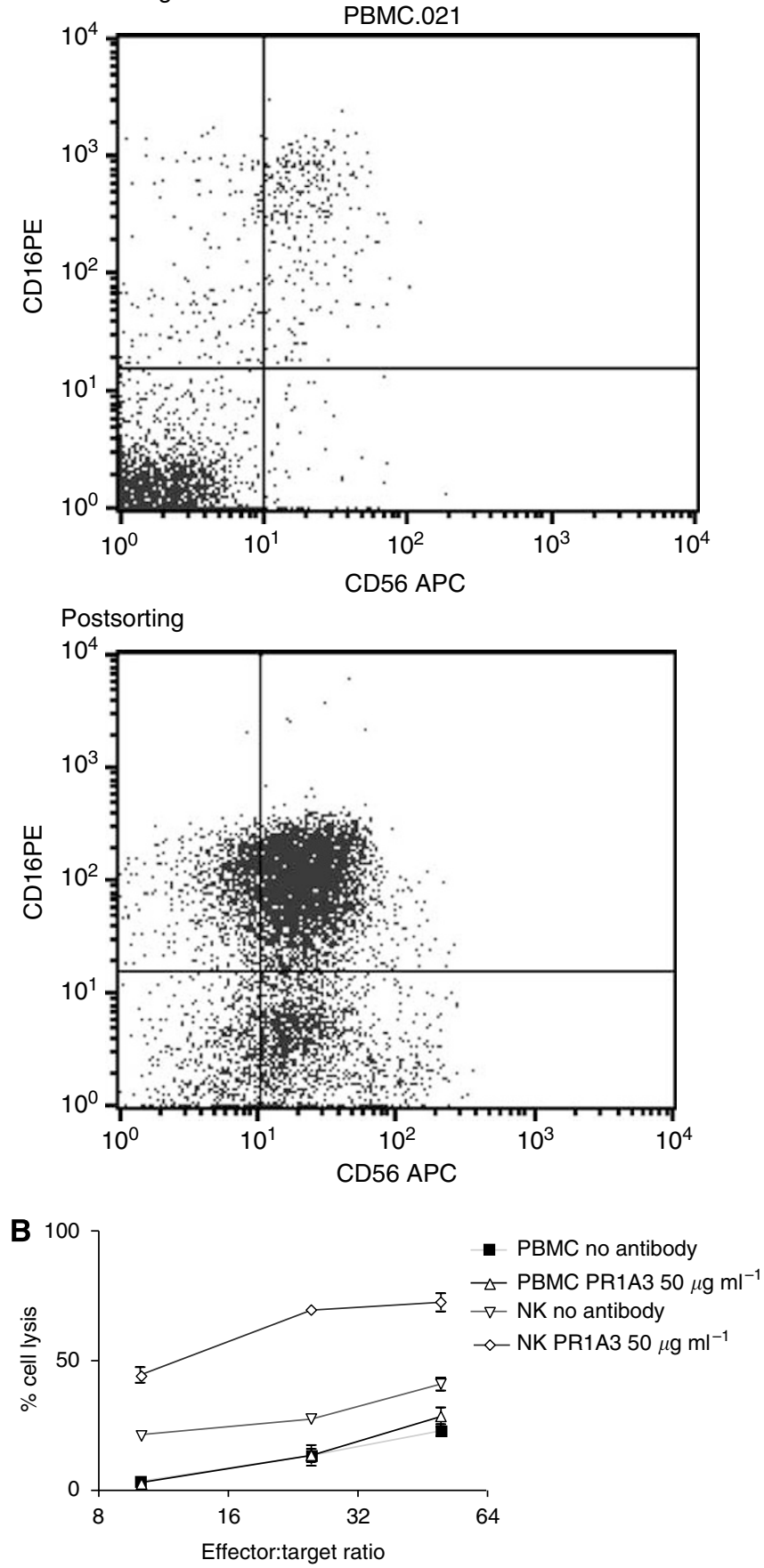

Figure 7 (A) Demonstration of NK cell purification. NK cells were purified from a single donor buffy coat sample (NBS) using the Human NK isolation kit. FACS analysis was performed using CD56 and CDI6 antibodies pre- and post-sorting to show the enrichment of NK cells, which are both CDI6- and CD56-positive. (B) Purified NK cells are much more effective killers than unfractionated PBMC. PBMC and NK cells were isolated from a single donor buffy coat (NBS). SKCO-I was used as the target in the presence of PBMC $(\triangle)$ or NK cells $(\diamond)$ with PRIA3 $\left(50 \mu \mathrm{g} \mathrm{ml}^{-1}\right)$, or with no antibody (PBMC, $\left.\mathbf{\square} ; \mathrm{NK}, \nabla\right)$. The flouresencebased EuTDA assay was used with effector:target ratios ranging from $10:$ । to $50: 1$.

from PBMCs obtained from buffy coat (NBS) using the Human NK Isolation kit, as described in Materials and Methods.

The extent of enrichment for NK cells is illustrated by the FACS analysis shown in Figure 7A, using antibodies to CD16 and CD56. 
The second panel clearly documents the extensive purification of the CD16 and CD56 positive NK cells. The results of ADCC assays with hPR1A3 using either these purified NK cells or unfractionated PBMCs as effectors, and SKCO-1 as target cells, are shown in Figure 7B. The difference in the effectiveness of killing by NK cells as compared to unfractionated PBMCs is striking. Whereas in both cases there is some spontaneous killing in the absence of antibody, the NK cell antibody-specific killing is already very clear at the lowest effector:target ratio of 10. There is, on the other hand, barely detectable specific killing with the PMBCs even at a 50:1 effector: target ratio. Further data (see Supplementary Figure 2) demonstrate that ADCC can occur in the presence of purified NK cells even at effector: target ratios as low as $1: 1$. These results provide strong support for the assumption that the hPR1A3 antibody-specific killing of CEA expressing human cell lines is almost entirely due to the action of the human NK cells as effectors.

\section{Neither hPR1A3 binding to, nor hPR1A3-mediated killing of MKN45 are blocked by soluble CEA}

The binding to the high expressing cell line SKCO-1 of hPR1A3 $\left(20 \mu \mathrm{g} \mathrm{ml}^{-1}\right)$ on its own, or after preincubation with soluble CEA $\left(10 \mu \mathrm{g} \mathrm{ml}^{-1}\right)$ was investigated using a FACS analysis. The results, illustrated in Figure 8A, show that there is no reduction in reactivity of hPR1A3 with MKN45 after preincubation with CEA, as compared to hPR1A3 alone. This corroborates for hPR1A3 the earlier results obtained by Durbin et al, 1994 with mPR1A3, which showed that soluble CEA does not block this antibody's binding to membrane bound CEA (Figure 8).

To show the same lack of effect of soluble CEA on hPR1A3specific killing, ADCC assays were carried out using fresh bloodderived NK cells and SKCO-1 as target cells with hPR1A3 on its own, or after preincubation with soluble CEA. The results, illustrated in Figure 8B, clearly show that even preincubation with $10 \mu \mathrm{g} \mathrm{ml}^{-1}$ of soluble CEA does not reduce the specific killing effect of hPR1A3.

\section{DISCUSSION}

Our study has clearly shown that the humanised PR1A3 antibody can be used for targeted killing of colorectal cancer lines that express cell surface CEA. Both the direct binding of the antibody to cells, and the extent of its ADCC activity against cells are dependant on the level of surface expression of CEA. The fact, as we have also shown, that CEA is not significantly internalised adds another advantage to CEA as a target for naked antibody therapy. This effectively increases the exposure times to $\mathrm{Fc} \gamma$ receptorbearing cells by promoting attachment to antibody-coated target cells. We have confirmed, as was shown previously for the murine version of PR1A3, that the binding of hPR1A3 to surface bound CEA is not inhibited by soluble CEA, and in addition have shown that the same is true for its ADCC activity. This property of PR1A3 accounts for the low false-positive rate of lymph node detection in immunoscintigraphy of colorectal cancers with PR1A3 in patients (Granowska et al, 1989), given that it has been shown that soluble CEA drains into lymphatics and so can become sequestrated into regional lymph nodes in the absence of cancer cells (Kubo et al, 1992).

Human NK cells are known to express CD16 (homologous to the Fc $\gamma$ IV receptor in mice (Nimmerjahn and Ravetch, 2005)) and are thought to play an important role in responses to antibody therapy (Liljefors et al, 2003). We have shown that the ADCC activity of hPR1A3 is dependent on its Fc domain. The evidence for this comes both from the fact that mPR1A3, though it binds to surface CEA on human cells, has no ADCC activity using human PBMC as effectors, and that the ADCC activity of hPR1A3 is blocked both by whole antibody to $\mathrm{CD} 16$ and by a CD16 F(ab') ${ }_{2}$ fragment. The fact that enrichment of human NK cells can elicit hPR1A3-dependent
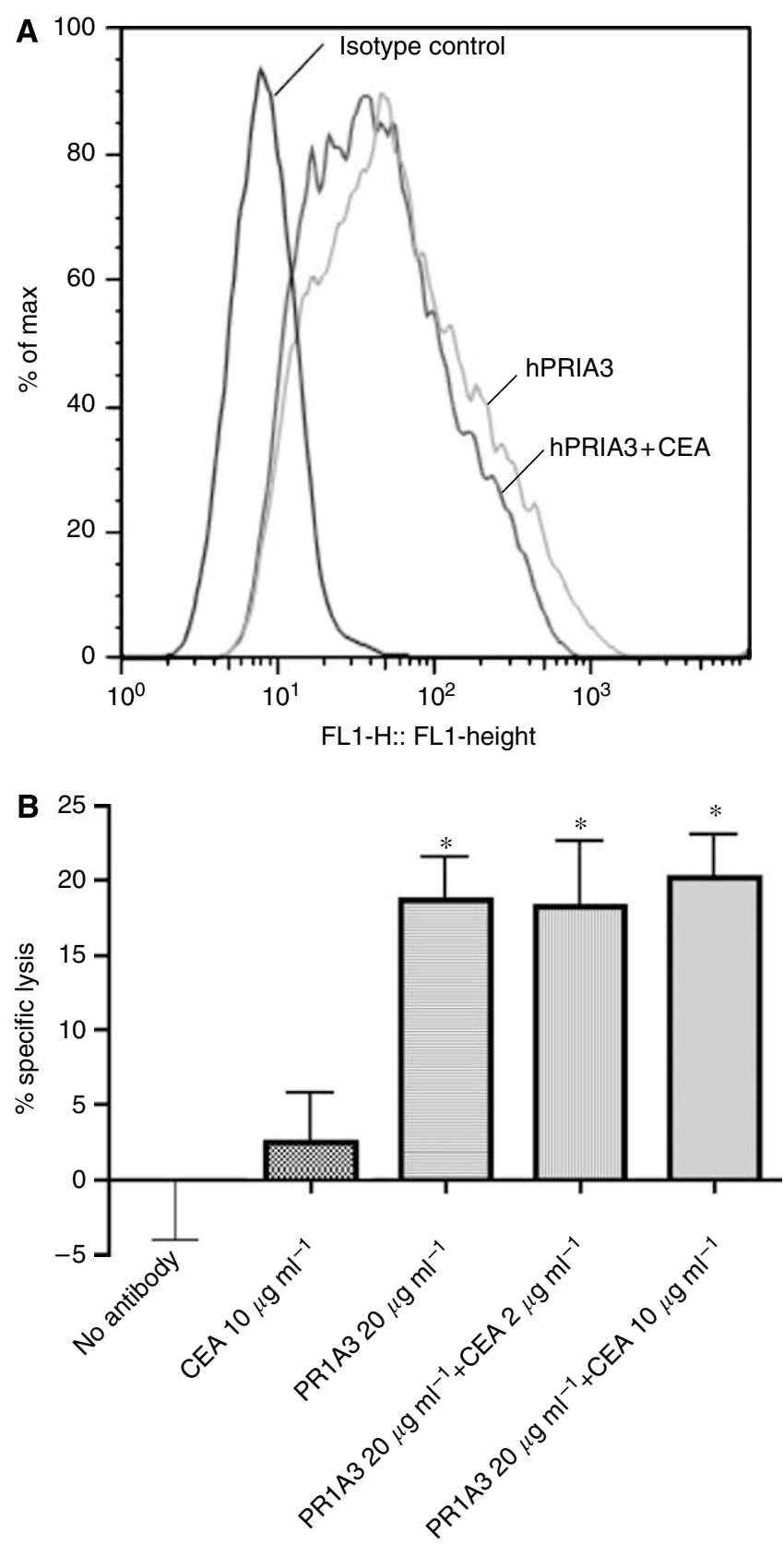

Figure 8 (A) Indirect staining and FACS analysis to study the effect of addition of soluble CEA on humanised PRIA3 binding to SKCO-I. The left histogram plot is the isotype control. The light grey curve represents the histogram curve for hPRIA3 only $\left(20 \mu \mathrm{gml}^{-1}\right)$ and the dark grey curve represents the curve for hPRIA3 $\left(20 \mu \mathrm{g} \mathrm{ml}{ }^{-1}\right)$ that has been preincubated with $10 \mu \mathrm{g} \mathrm{ml}^{-1}$ of soluble CEA. (B) ADCC assay with hPRIA3 on its own, or after preincubation with soluble CEA at final concentrations of 2 and $10 \mu \mathrm{g} \mathrm{ml}^{-1}$, using purified NK cells (CD56+/CD I6+/CD3-) as effectors and fluorescently labelled SKCO-I cells as targets (effector:target ratio used was 10:1). The controls used were no antibody and purified CEA with target and effector cells only. *Indicates $P<0.05$ compared with the specific lysis of target and effector cells alone.

ADCC at very low effector:target ratios when compared with unfractionated PBMC, provides strong evidence that the ADCC activity of hPR1A3 is actually mediated by human NK cells. That the addition of the complete CD16 IgG, (but not the $\mathrm{F}(\mathrm{ab})_{2}$ fragment) also abolishes antibody independent killing may be explained either by antibody binding to CD16-bearing cells 
reducing their mobility in the wells due to formation of clusters of $\mathrm{CD} 16+$ cells or that killer cells may destroy CD16 + cells which have bound the antibody.

The affinity of hPR1A3 for CEA appears to be relatively low as reflected by the higher concentrations of PR1A3 needed to mediate ADCC as compared to cetuximab (see Supplementary Figure 2). However, this may be a potential advantage in the treatment of solid tumours, since higher affinity antibodies may penetrate less into tumours due to the majority of binding taking place at the outer most part of a tumour (Adams et al, 2001). Intermediate affinity antibodies may, thus, be predicted to have greater penetration into solid tumours.

Much research is now directed at conjugating antibodies with radiolabels or toxins. Although this has had some success in experimental animal models, there remain significant problems in the true in vivo situation, including especially the development of an immune response against the toxins or enzymes linked to a therapeutic antibody.

We suggest that the appropriateness of CEA as a therapeutic target, together with our evaluation of antibody hPR1A3's mediated ADCC activity makes this antibody a very attractive target for clinical development as a naked antibody. The main challenge may be to enhance PR1A3's ADCC activity, and this may be achieved by glycoengineering its $\mathrm{Fc}$ hinge region (Umana et al, 1999), which has been shown to be a very effective method for enhancing the effectiveness of antibody-mediated ADCC in vitro.

As previously discussed, only a small percentage of antibody administered intravenously actually reaches the cells of a solid tumour ((Allum et al, 1986; Delaloye et al, 1986; Epenetos et al, 1986; Colcher et al, 1987; Welt et al, 1990). While a small number of antibody molecules reaching their tumour target may be sufficient to elicit immune-based killing by ADCC, it seems

\section{REFERENCES}

Adams GP, Schier R, McCall AM, Simmons HH, Horak EM, Alpaugh RK, Marks JD, Weiner LM (2001) High affinity restricts the localization and tumor penetration of single-chain $\mathrm{fv}$ antibody molecules. Cancer Res 61: $4750-4755$

Allum WH, MacDonald F, Anderson P, Fielding JW (1986) Localisation of gastrointestinal cancer with a 131 I labelled monoclonal antibody to CEA. Br J Cancer 53: 203-210

Arnould L, Gelly M, Penault-Llorca F, Benoit L, Bonnetain F, Migeon C, Cabaret V, Fermeaux V, Bertheau P, Garnier J, Jeannin JF, Coudert B (2006) Trastuzumab-based treatment of HER2-positive breast cancer: an antibody-dependent cellular cytotoxicity mechanism? Br J Cancer 94: 259-267

Berinstein NL (2002) Carcinoembryonic antigen as a target for therapeutic anticancer vaccines: a review. J Clin Oncol 20: 2197-2207

Blomberg K, Hautala R, Lovgren J, Mukkala VM, Lindqvist C, Akerman K (1996) Time-resolved fluorometric assay for natural killer activity using target cells labelled with a fluorescence enhancing ligand. J Immunol Methods 193: 199-206

Boyum A (1968) Separation of leukocytes from blood and bone marrow. Introduction. Scand J Clin Lab Invest Suppl 97: 7

Brattain MG, Fine WD, Khaled FM, Thompson J, Brattain DE (1981) Heterogeneity of malignant cells from a human colonic carcinoma. Cancer Res 41: 1751-1756

Browning MJ, Krausa P, Rowan A, Hill AB, Bicknell DC, Bodmer JG, Bodmer WF (1993) Loss of human leukocyte antigen expression on colorectal tumor cell lines: implications for anti-tumor immunity and immunotherapy. J Immunother 14: 163-168

Carter PJ (2006) Potent antibody therapeutics by design. Nat Rev Immunol 6: $343-357$

Chan CH, Stanners CP (2007) Recent advances in the tumour biology of the GPI-anchored carcinoembryonic antigen family members CEACAM5 and CEACAM6. Curr Oncol 14: 70-73

Chau I, Allen MJ, Cunningham D, Norman AR, Brown G, Ford HE, Tebbutt N, Tait D, Hill M, Ross PJ, Oates J (2004) The value of routine serum carcino-embryonic antigen measurement and computed unlikely that such small amounts of antibody reaching a tumour could have much effect in blocking function, since this would require at least the majority of the antibody's targets to be covered. This emphasises the potential importance of immune mechanisms, even for therapy with antibodies against targets such as EGFR and ErbB with known functions, and so the importance of enhancing ADCC for effective treatment, rather than improving the blocking of function. The fact that CEA has no obvious function that might be blocked by antibody does not mitigate against its use for naked antibody-based therapy on the assumption that the primary mechanism is immune and through ADCC. We believe that the results we have presented here suggest that the naked anti-CEA humanised antibody PR1A3, glycoengineered to increase its efficacy in ADCC, may be an excellent candidate for therapy of colorectal and other solid tumours that express significant levels of CEA.

\section{ACKNOWLEDGEMENTS}

PJC was supported by generous grants from the CORE charity and the Jacqueline Seroussi Memorial Foundation for Cancer Research. SQA was supported by a Bobby Moore Research Fellowship, CRUK. MGT was supported by generous grants from the Royal College of Surgeons of England and a grant from the John Radcliffe Charitable Trust. The overall work in the laboratory is funded by a Cancer Research UK programme grant to WFB. We thank Sylvia Bartlett and Rose Dorupi for their help and support.

Supplementary Information accompanies the paper on British Journal of Cancer website (http://www.nature.com/bjc) tomography in the surveillance of patients after adjuvant chemotherapy for colorectal cancer. J Clin Oncol 22: 1420-1429

Clynes R (2006) Antitumor antibodies in the treatment of cancer: Fc receptors link opsonic antibody with cellular immunity. Hematol Oncol Clin North Am 20: 585-612

Clynes R, Takechi Y, Moroi Y, Houghton A, Ravetch JV (1998) Fc receptors are required in passive and active immunity to melanoma. Proc Natl Acad Sci USA 95: 652-656

Colcher D, Esteban JM, Carrasquillo JA, Sugarbaker P, Reynolds JC, Bryant G, Larson SM, Schlom J (1987) Quantitative analyses of selective radiolabeled monoclonal antibody localization in metastatic lesions of colorectal cancer patients. Cancer Res 47: 1185-1189

Delaloye B, Bischof-Delaloye A, Buchegger F, von Fliedner V, Grob JP, Volant JC, Pettavel J, Mach JP (1986) Detection of colorectal carcinoma by emission-computerized tomography after injection of 123I-labeled Fab or $\mathrm{F}(\mathrm{ab}) 2$ fragments from monoclonal anti-carcinoembryonic antigen antibodies. J Clin Invest 77: $301-311$

Durbin H, Bodmer WF (1987) A sensitive micro-immunoassay using betagalactosidase/anti-beta-galactosidase complexes. J Immunol Methods 97: $19-27$

Durbin H, Young S, Stewart LM, Wrba F, Rowan AJ, Snary D, Bodmer WF (1994) An epitope on carcinoembryonic antigen defined by the clinically relevant antibody PR1A3. Proc Natl Acad Sci USA 91(10): 4313-4317

Epenetos AA, Canti G, Taylor-Papadimitriou J, Curling M, Bodmer WF (1982) Use of two epithelium-specific monoclonal antibodies for diagnosis of malignancy in serous effusions. Lancet 2: 1004-1006

Epenetos AA, Snook D, Durbin H, Johnson PM, Taylor-Papadimitriou J (1986) Limitations of radiolabeled monoclonal antibodies for localization of human neoplasms. Cancer Res 46: 3183-3191

Fogh J, Trempe G (1975) Human Tumour Cells In Vitro. Plenum Press: New York

Gold P, Freedman SO (1965) Demonstration of tumor-specific antigens in human colonic carcinomata by immunological tolerance and absorption techniques. J Exp Med 121: 439-462 
Granowska M, Jass JR, Britton KE, Northover JM (1989) A prospective study of the use of 111 In-labelled monoclonal antibody against carcinoembryonic antigen in colorectal cancer and of some biological factors affecting its uptake. Int J Colorectal Dis 4: $97-108$

Hammarstrom S (1999) The carcinoembryonic antigen (CEA) family: structures, suggested functions and expression in normal and malignant tissues. Semin Cancer Biol 9: 67-81

Kubo A, Nakamura K, Katayama M, Hashimoto S, Teramoto T, Kodaira S (1992) Pharmacokinetic analysis of antibody localization in human colon cancer: comparison with immunoscintigraphy. Ann Nucl Med 6: $21-27$

Lanier LL, Ruitenberg JJ, Phillips JH (1988) Functional and biochemical analysis of CD16 antigen on natural killer cells and granulocytes. J Immunol 141: $3478-3485$

Liersch T, Meller J, Bittrich M, Kulle B, Becker H, Goldenberg DM (2007) Update of carcinoembryonic antigen radioimmunotherapy with (131)ilabetuzumab after salvage resection of colorectal liver metastases: comparison of outcome to a contemporaneous control group. Ann Surg Oncol 14: $2577-2590$

Liljefors M, Nilsson B, Hjelm Skog AL, Ragnhammar P, Mellstedt H, Frodin JE (2003) Natural killer (NK) cell function is a strong prognostic factor in colorectal carcinoma patients treated with the monoclonal antibody 17-1A. Int J Cancer 105: 717-723

Lubeck MD, Steplewski Z, Baglia F, Klein MH, Dorrington KJ, Koprowski H (1985) The interaction of murine IgG subclass proteins with human monocyte Fc receptors. J Immunol 135: $1299-1304$

Moretta A, Tambussi G, Ciccone E, Pende D, Melioli G, Moretta L (1989) CD16 surface molecules regulate the cytolytic function of CD3CD16+ human natural killer cells. Int J Cancer 44: 727-730

Motoyama T, Hojo H, Suzuki T, Oboshi S (1979) Evaluation of the regrowth assay method as an in vitro drug sensitivity test and its application to cultuered human gastric cancer cell lines. Acta Medica et Biologica 27: $49-63$

Nimmerjahn F, Ravetch JV (2005) Divergent immunoglobulin g subclass activity through selective Fc receptor binding. Science 310: 1510-1512

Olszewski AJ, Grossbard ML (2004) Empowering targeted therapy: lessons from rituximab. Sci STKE 2004: pe30

Paraskeva C, Buckle BG, Sheer D, Wigley CB (1984) The isolation and characterization of colorectal epithelial cell lines at different stages in malignant transformation from familial polyposis coli patients. Int J Cancer 34: 49-56

Reichert JM, Valge-Archer VE (2007) Development trends for monoclonal antibody cancer therapeutics. Nat Rev Drug Discov 6: 349-356
Richman PI, Bodmer WF (1987) Monoclonal antibodies to human colorectal epithelium: markers for differentiation and tumour characterization. Int J Cancer 39: 317-328

Solic N, Collins JE, Richter A, Holt SJ, Campbell I, Alexander P, Davies DE (1995) Two newly established cell lines derived from the same colonic adenocarcinoma exhibit differences in EGF-receptor ligand and adhesion molecule expression. Int J Cancer 62: 48-57

Spurr NK, Durbin H, Sheer D, Parkar M, Bobrow L, Bodmer WF (1986) Characterization and chromosomal assignment of a human cell surface antigen defined by the monoclonal antibody AUAI. Int J Cancer 38: $631-636$

Stewart LM, Young S, Watson G, Mather SJ, Bates PA, Band HA, Wilkinson RW, Ross EL, Snary D (1999) Humanisation and characterisation of PR1A3, a monoclonal antibody specific for cell-bound carcinoembryonic antigen. Cancer Immunol Immunother 47: 299-306

Thompson JA, Grunert F, Zimmermann W (1991) Carcinoembryonic antigen gene family: molecular biology and clinical perspectives. J Clin Lab Anal 5: $344-366$

Titus JA, Perez P, Kaubisch A, Garrido MA, Segal DM (1987) Human K/ natural killer cells targeted with hetero-cross-linked antibodies specifically lyse tumor cells in vitro and prevent tumor growth in vivo. J Immunol 139: $3153-3158$

Tom BH, Rutzky LP, Jakstys MM, Oyasu R, Kaye CI, Kahan BD (1976) Human colonic adenocarcinoma cells. I. Establishment and description of a new line. In vitro 12: $180-191$

Umana P, Jean-Mairet J, Moudry R, Amstutz H, Bailey JE (1999) Engineered glycoforms of an antineuroblastoma IgG1 with optimized antibody-dependent cellular cytotoxic activity. Nat Biotechnol 17: 176-180

Watkins JF, Sanger C (1977) Properties of a cell line from human adenocarcinoma of the rectum. Br J Cancer 35: 785-794

Welt S, Divgi CR, Real FX, Yeh SD, Garin-Chesa P, Finstad CL, Sakamoto J, Cohen A, Sigurdson ER, Kemeny N (1990) Quantitative analysis of antibody localization in human metastatic colon cancer: a phase I study of monoclonal antibody A33. J Clin Oncol 8: 1894-1906

Wiratkapun S, Kraemer M, Seow-Choen F, Ho YH, Eu KW (2001) High preoperative serum carcinoembryonic antigen predicts metastatic recurrence in potentially curative colonic cancer: results of a five-year study. Dis Colon Rectum 44: $231-235$

Wong JY, Chu DZ, Williams LE, Yamauchi DM, Ikle DN, Kwok CS, Liu A, Wilczynski S, Colcher D, Yazaki PJ, Shively JE, Wu AM, Raubitschek AA (2004) Pilot trial evaluating an 123I-labeled 80-kilodalton engineered anticarcinoembryonic antigen antibody fragment (cT84.66 minibody) in patients with colorectal cancer. Clin Cancer Res 10: 5014-5021 